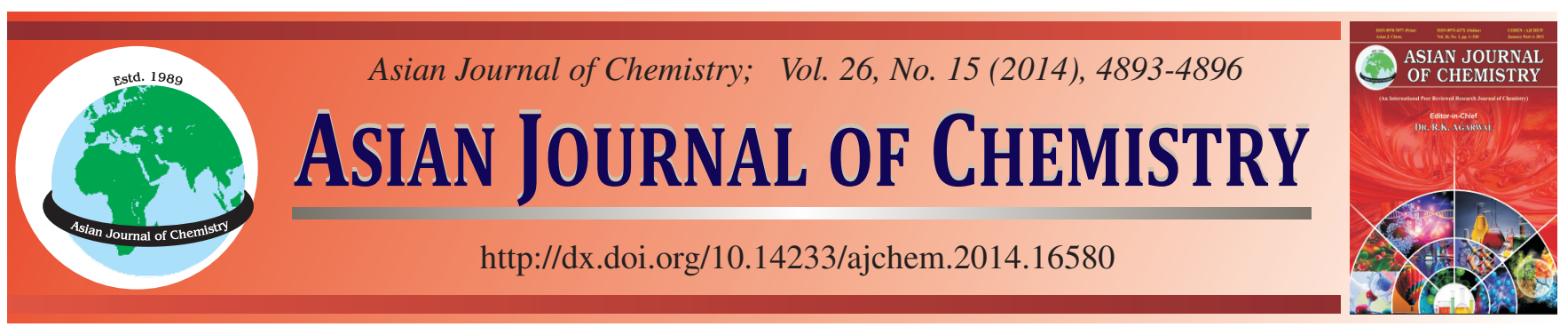

\title{
Pyrolysis Characteristics of Different Humectant at High Temperature
}

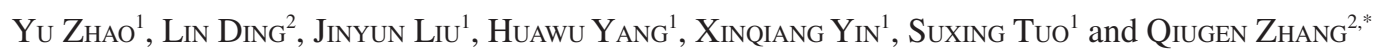

${ }^{1}$ Technology Center of China Tobacco Hunan Industrial Corporation, Changsha 410007, Hunan Province, P.R. China

${ }^{2}$ Key Laboratory of Jiangxi Province for Persistent Pollutants Control and Resources Recycle, Nanchang Hangkong University, Nanchang 330063 , P.R. China

*Corresponding author: Fax: +86 791 8395373; Tel: +86 791 83953372; E-mail: niatzqg@163.com

Humectants is indispensable in the cigarettes. The pyrolysis characteristics of different humectant have a great significance to reduce the noxious substance which come from cigarette smoke. In this paper, experimental process is based on simulates cigarette combustion. Further research on pyrolysis of several major humectants. GC-MS analysis of products retrieved from pyrolysis reaction shows that glycol, glycerin and 27664 are prone to evaporate during pyrolysis due to its low boiling point and chemical instability, instead of vaporization, xylitol and sorbitol pyrolyzed into aldehyde, ketone and alcohol.

Keywords: Cigarettes, Humectants, Pyrolysis, GC-MS analysis.

\section{INTRODUCTION}

Humectants are used in cigarettes for several purposes, including the facilitation of the cutting of tobacco (acting as a lubricant for the cutting knives) into appropriate width tobacco shreds ${ }^{1}$. Their major purpose is to maintain the moisture level of the tobacco blend. If cigarettes lose moisture during transportation, warehouse storage, shelf life, etc., their smoke composition changes drastically ${ }^{1}$.

Once a cigarette is ignited, chemical compositions inside it will lead to a series of complicated chemical reactions. Meanwhile, the smoke which is formed through diffusion, not only contains diverse aroma components, but also produces noxious substance ${ }^{2,3}$. For example, carbon monoxide, nitride oxides, volatile aromatic hydrocarbon, hydrogen cyanide and volatile carbonyl compounds gathered in the gaseous phase, while polycyclic aromatic hydrocarbon, $\mathrm{N}$-nitrosamines, radical, some heterocyclic compounds and radioactive substances coexist as particulates. Although some substances are in low density, they can still be detrimental to heath, especially those with carcinogenic activity ${ }^{4}$. Therefore, chemical compositions of tobacco are closely related with the quality of cigarettes. The chemicals which formed on the burning of these chemical composition, affect the fragrance and human health in varied extent, not only in the aspect of the color of tobacco but also in relation with noxious substance which come from smoke.

The importance and interest in the study of the processes of pyrolysis and oxidation of tobacco and the different ingredients used in the fabrication of commercial cigarettes has been recognized from years ${ }^{5}$. As a technique, pyrolysis can provide valuable data, according to these results, points out that the relation between smoking and the data. In this paper, experimental process is based on simulates cigarette combustion ${ }^{6}$. Further research on pyrolysis of several major humectants, which are common in tobacco industry, helps to elucidate impacts of different humectants on cigarette combustion. Besides, we use GC-MS analysis of the pyrolysis products.

\section{EXPERIMENTAL}

Propylene glycol, glycerin, xylitol and sorbitol (more than 98 w \%) were purchased from Sigma Co., Ltd.; PY-2020 is cracker was purchased from Japan Frontier Co., Ltd.; GCMSQP2010 gas chromatography mass spectrometry was purchased from Japan SHIMADZU Co., Ltd.; DB-5 capillary column $(30 \mathrm{~m} \times 0.25 \mathrm{~mm} \times 0.25 \mu \mathrm{m}) ; 27664$ was prepared by ourselves.

Operation condition of GC-MS: Gasified temperature was $280{ }^{\circ} \mathrm{C}$. Carrier gas was highly purified helium. Column flow was $0.8 \mathrm{~mL} / \mathrm{min}$. Injection mode was split and split ratio was 100:1. The oven temperature was programmed in three ramps, initially $40{ }^{\circ} \mathrm{C}$ isothermally for $4 \mathrm{~min}$, then from 40 to $280^{\circ} \mathrm{C}$ at $10^{\circ} \mathrm{C} / \mathrm{min}$ and finally $280^{\circ} \mathrm{C}$ isothermally for $2 \mathrm{~min}$. The mass spectrometry detection system was operated at $70 \mathrm{eV}$ full scan $\mathrm{m} / \mathrm{z}$ from 15 to $500 \mathrm{amu}$. The ion source temperature was $200{ }^{\circ} \mathrm{C}$, the interface temperature was $380{ }^{\circ} \mathrm{C}$ and the ionization mode was EI. 
General procedure: A certain amount (about $2 \mathrm{mg}$ ) of propylene glycol, glycerin, 27664, xylitol and sorbitol were added into quartz tube dedicated to splitting and then the quartz tube was put into the heater strip of PY-2020 is cracker at 300, 450, 600 and $750{ }^{\circ} \mathrm{C}$, respectively, under the atmosphere of nitrogen for splitting. Finally, the products in pyrolysis room were extracted using SPME head for 2-3 min and then the sample was injected into GC-MS system for analysis.

Calculation of quantity of the pyrolysis product: The quantity of each product is analyzed by the area normalization method and displayed by the percentage of peak area.

\section{RESULTS AND DISCUSSION}

By using the above method to analyze the pyrolysis products, which are produced by different products of propylene glycol, glycerol, 27664, xylitol and sorbitol at 300, 450, 600 and $750{ }^{\circ} \mathrm{C}$, the standard spectrum library retrieval of pyrolysis products and relative content are shown in Tables 1-5.

As can be seen from the Table-1, propylene glycol only detected a substance under the condition of $300{ }^{\circ} \mathrm{C}$, namely, propylene glycol and the content of propylene glycol is $94.62 \%$, indicating that propylene glycol pyrolysis almost did not happen. According to the literature ${ }^{7}$, during the thermal decomposition of propylene glycol, only a small fraction (5-12.6\%) of propylene glycol transfer to mainstream smoke volatile and part of propylene glycol thermally cracks into water, acetone, propionaldehyde and carbon dioxide. Compared to the content of benzopyrene generated by the pyrolysis of the tobacco itself, the benzopyrenne generated by the pyrolysis of propylene glycol is minimal. Under the condition of $450{ }^{\circ} \mathrm{C}$, propylene glycol began to have configurational change, parts of them transform into R-(-)-1,2-propylene glycol, which indicates that propylene glycol in the description of the temperature turns into unstable state. Under the condition of $600{ }^{\circ} \mathrm{C}$, propylene glycol cracks into propylene, aldehyde, methyl vinyl ether, hydroxyacetone and 2-propylene-1alcohol, the dehydration product of propylene glycol, while some R-(-)-1,2-propanediol configurationally pyrolysis products change back into 1,2-propylene glycol, indicating that under the conditions of a temperature of $450-600{ }^{\circ} \mathrm{C}$, pyrolysis products 1,2-propanediol optically prone to change. Pyrolysis products of pyrolysis product under the condition of $750{ }^{\circ} \mathrm{C}$ is basically the same to the condition of $600{ }^{\circ} \mathrm{C}$, with an increasing content of pyrolysis products of propylene and vinyl ether pyrolysis, the content of propylene glycol began a sharp decline. As can be seen from the pyrolysis products, in addition to trace amounts of toxic substances acetaldehyde, other pyrolysis substances generated have no significant adverse effects on the quality of cigarette whose propylene glycol sample itself does not happen glycol pyrolysis changed much.

Table- 2 showed that the glycerol is not much involved in pyrolysis at $300-450{ }^{\circ} \mathrm{C}$. When the temperature is above $600{ }^{\circ} \mathrm{C}$. The content of glycerol decreased greatly as the pyrolysis temperature changes. In the pyrolysis process, about $5 \%$ glycerol volatilizing transferred to mainstream smoke, about $30 \%$ stranded in the cigarette holder and $4 \%$ stranded in tipping paper. The pyrolysis products of glycerol include
TABLE-1

PYROLYSIS PRODUCTS OF THE PROPYLENE GLYCOL AT DIFFERENT TEMPERATURES

\begin{tabular}{ccllcccc}
\hline \multirow{2}{*}{ No. } & $\begin{array}{c}\text { Residence } \\
\text { time (min) }\end{array}$ & \multicolumn{1}{c}{ Products } & \multicolumn{4}{c}{ Relative content (\%) } \\
\cline { 3 - 7 } & & $300{ }^{\circ} \mathrm{C}$ & $450{ }^{\circ} \mathrm{C}$ & $600{ }^{\circ} \mathrm{C}$ & $750{ }^{\circ} \mathrm{C}$ \\
\hline 1 & 1.605 & Propylene & - & 0.09 & 0.97 & 5.41 \\
2 & 1.655 & Acetaldehyde & - & - & 0.14 & 1.96 \\
3 & 1.845 & Vinyl ether & - & 0.04 & 0.79 & 13.45 \\
4 & 2.045 & 2-Propylene-1- & - & - & 0.03 & 0.65 \\
& & alcohol & & & & \\
5 & 2.090 & Propanol & - & 0.01 & 0.03 & 0.16 \\
6 & 2.945 & Acetone alcohol & - & 0.22 & 0.15 & 1.16 \\
7 & 7.570 & $\begin{array}{l}\text { 1,2-Propylene } \\
\text { glycol }\end{array}$ & 96.62 & 89.24 & 92.97 & 77.05 \\
& & & & & \\
8 & 22.085 & $\begin{array}{l}\text { R-(-)-1,2- } \\
\text { Propanediol }\end{array}$ & - & 10.37 & 4.9 & - \\
\hline
\end{tabular}

acetone, acetaldehyde, water and acrolein ${ }^{8}$. At $600{ }^{\circ} \mathrm{C}$, the sample would generate some harmful substances like formaldehyde, acrolein, acetone formaldehyde, but in a very small quantity. Pyrolysis products content at $750{ }^{\circ} \mathrm{C}$ is basically same to the content at $600{ }^{\circ} \mathrm{C}$ and the content of pyrolysis products rose sharply while its own content decreased. Meanwhile at $750^{\circ} \mathrm{C}$ conditions, acetone alcohol and glycidol are not found, indicating that under the conditions of $600{ }^{\circ} \mathrm{C}$, as the temperature rises, two kinds of pyrolysis products were further cleaved to generate other products. As can be seen from the pyrolysis product, at $750{ }^{\circ} \mathrm{C}$, glycerol is only $64.86 \%$ of the pyrolysis products of glycerin samples, while under the same conditions, there would be still $77.05 \%$ of propylene glycol, which indicates that glycerol is more easier to pyrolysis at that temperature, whose boiling point is higher than propylene glycol and volatility is worse. With the increasing of the pyrolysis temperature, the content of low molecular aldehydes and ketones (especially propylene aldehyde), produced by the pyrolysis of glycerol, is increased and which is not conducive to the tobacco harm reduction, thus, we should properly control the amount of humectant.

\begin{tabular}{|c|c|c|c|c|c|c|}
\hline & GLYC & $\begin{array}{l}\text { TA } \\
\text { PYROLYSIS PI } \\
\text { CERIN AT DIFFH }\end{array}$ & $\begin{array}{l}\text { LE-2 } \\
\text { ODUCT } \\
\text { RENT T }\end{array}$ & $\begin{array}{l}\text { OF TH } \\
\text { MPER }\end{array}$ & URES & \\
\hline & Residence & & & Relative & ntent $(\%$ & \\
\hline No. & $\begin{array}{l}\text { time } \\
\text { (min) }\end{array}$ & cts & $300^{\circ} \mathrm{C}$ & $450^{\circ} \mathrm{C}$ & $600^{\circ} \mathrm{C}$ & $750^{\circ} \mathrm{C}$ \\
\hline 1 & 1.565 & Carbon dioxide & - & 0.36 & 0.49 & 3.20 \\
\hline 2 & 1.585 & Formaldehyde & - & - & 0.54 & 2.52 \\
\hline 3 & 1.820 & 2-Acrolein & - & - & 0.75 & 4.67 \\
\hline 4 & 1.835 & Methylglyoxal & - & - & 0.26 & 1.13 \\
\hline 5 & 2.035 & $\begin{array}{l}\text { 2-propylene-1- } \\
\text { alcohol }\end{array}$ & - & - & 1.55 & 7.34 \\
\hline 6 & 2.165 & Acetaldehyde & - & 0.01 & 0.24 & 3.36 \\
\hline 7 & 2.940 & Acetone alcohol & - & 0.05 & 0.06 & - \\
\hline 8 & 3.605 & Glycidol & - & 0.06 & 0.17 & - \\
\hline 9 & 4.030 & $\begin{array}{l}\text { Formic acid-2- } \\
\text { acrylic ester }\end{array}$ & - & - & 0.02 & 0.28 \\
\hline 10 & 17.810 & Glycerol & 99.62 & 99.35 & 95.84 & 64.86 \\
\hline
\end{tabular}

Table- 3 suggested that under the conditions of $300{ }^{\circ} \mathrm{C}$, the pyrolysis behavior of the sample 27664 is similar to glycerol and the basic pyrolysis does not occur. At $450-600{ }^{\circ} \mathrm{C}$, the sample 27664 partially pyrolyzed to the form of carbon dioxide and trace amounts of acrolein, 2-propylene-1-alcohol, 


\begin{tabular}{|c|c|c|c|c|c|c|}
\hline & PYF & $\begin{array}{r}\text { TABL } \\
\text { ROLYSIS PRODU } \\
\text { AT DIFFERENT TI }\end{array}$ & $\begin{array}{l}\text { E-3 } \\
\text { CTS OF } \\
\text { EMPER }\end{array}$ & $\begin{array}{l}\text { THE } 27 \\
\text { ATURE }\end{array}$ & & \\
\hline & Residence & & & elative c & ntent $(\%$ & \\
\hline No. & $\begin{array}{l}\text { time } \\
(\min )\end{array}$ & Products & $300^{\circ} \mathrm{C}$ & $450^{\circ} \mathrm{C}$ & $600^{\circ} \mathrm{C}$ & $750^{\circ} \mathrm{C}$ \\
\hline 1 & 1.560 & Carbon dioxide & - & 4.14 & 0.54 & 3.20 \\
\hline 2 & 1.580 & Formaldehyde & - & - & 3.13 & 3.01 \\
\hline 3 & 1.645 & Acetaldehyde & - & - & - & 3.52 \\
\hline 4 & 1.810 & 2-Acrolein & - & 0.25 & 0.86 & 2.22 \\
\hline 5 & 1.825 & Acetone & - & - & - & 4.86 \\
\hline 6 & 2.085 & $\begin{array}{l}\text { 2-propylene-1- } \\
\text { alcohol }\end{array}$ & - & 0.59 & 2.26 & 5.34 \\
\hline 7 & 3.410 & Acetone alcohol & 0.78 & - & - & - \\
\hline 8 & 3.700 & Oxiranemethanol & 0.12 & - & 0.11 & - \\
\hline 9 & 9.630 & $\begin{array}{l}\text { 3-Methyl- } \\
\text { cyclopentane- } \\
1,2 \text {-dione }\end{array}$ & 0.37 & 0.62 & 0.49 & - \\
\hline 10 & 12.725 & $\begin{array}{l}1,4,3,6- \\
\text { Dianhydro- } \alpha-d \\
\text {-glucopyranose }\end{array}$ & 0.80 & 0.92 & 0.74 & 0.46 \\
\hline 11 & 17.575 & Glycerol & 97.54 & 92.28 & 89.54 & 75.22 \\
\hline
\end{tabular}

3-methyl-cyclopentane-1,2-dione, 1,4,3,6-dianhydro- $\alpha$-dglucopyranose and content of glycerol itself was maintained at about $90 \%$, indicating that at the range of $450-600{ }^{\circ} \mathrm{C}$, 27664 samples occurs a partial pyrolysis. In the range of $450-$ $600{ }^{\circ} \mathrm{C}$, the glycerol content of the sample is still maintained at $95 \%$, indicating that the glycerol degradation behavior is basically in volatile way to transfer and its boiling point is lower than 27664 's and volatility is weaker. When the temperature increased to $750{ }^{\circ} \mathrm{C}$, the pyrolysis product was significantly increased and glycerol content decreased $(75.22 \%)$, resulting in a certain content of carbon dioxide and traces of aldehydes and ketones, where in the content of product 1,4,3,6dianhydro- $\alpha$-d-glucopyranose gradually decreased to $0.46 \%$. Respecting to high contents of acrolein $(4.67 \%$ ) produced by the pyrolysis of the sample glycerol, the pyrolysis of sample 27664 produces acrolein content of only $2.22 \%$, whether this content of acrolein will affect the taste of cigarettes requires further experiment to verify.

From the Table-4, it is clear that the pyrolyzates of xylitol sample is similar to the pyrolysates of hexose. At $300{ }^{\circ} \mathrm{C}$, it generates 9 types of furfural, furan and sugar alcohols, in which the content of 5-hydroxymethyl furfural is the highest, reaching about $50 \%$. With the increase of pyrolysis temperature and the condition of $450{ }^{\circ} \mathrm{C}$, content of carbon dioxide produced by pyrolysis of xylitol rapidly increases and the content of 5-hydroxymethyl furfural (31.99\%) and the content of 1,6anhydro- $\beta$-D-glucopyranose (6.13\%) began to decline. At 600 ${ }^{\circ} \mathrm{C}$, the carbon dioxide content in the pyrolysis product of xylitol is up to $40 \%$ and a content of formaldehyde $(4.03 \%)$ and glycolaldehyde $(2.48 \%)$ are detected, corresponding to the decline of some pyrolysis products, such as furfural, ethanol. While 2,5-dimethyl-4-hydroxy-3(2H)-furanone and methyl 2-furoate, the pyrolysis products produced at $450{ }^{\circ} \mathrm{C}$, cannot be detected at $600{ }^{\circ} \mathrm{C}$. Content of carbon dioxide and 2 -furfuryl alcohol generated at $750^{\circ} \mathrm{C}$, was significantly reduced $(22.99 \%)$, content of formaldehyde, methylglyoxal and other harmful substances increase, in which the newly generated butanedial $(6.47 \%)$ and 5-hydroxymethyl furfural content

\begin{tabular}{|c|c|c|c|c|c|c|}
\hline \multicolumn{7}{|c|}{$\begin{array}{c}\text { TABLE-4 } \\
\text { PYROLYSIS PRODUCTS OF THE XYLITOL } \\
\text { AT DIFFERENT TEMPERATURES }\end{array}$} \\
\hline \multirow{2}{*}{ No. } & \multirow{2}{*}{$\begin{array}{l}\text { Residence } \\
\text { time } \\
\text { (min) }\end{array}$} & \multirow{2}{*}{ Products } & \multicolumn{4}{|c|}{ Relative content (\%) } \\
\hline & & & $300^{\circ} \mathrm{C}$ & $450^{\circ} \mathrm{C}$ & $600^{\circ} \mathrm{C}$ & $750^{\circ} \mathrm{C}$ \\
\hline 1 & 1.545 & Carbon dioxide & - & 24.51 & 39.53 & 22.99 \\
\hline 2 & 1.600 & Formaldehyde & - & - & 4.03 & 9.93 \\
\hline 3 & 1.645 & Butanedial & - & - & - & 6.47 \\
\hline 4 & 1.730 & Ethanol & 2.69 & 6.56 & 1.50 & 3.69 \\
\hline 5 & 1.825 & Methylglyoxal & - & - & - & 20.54 \\
\hline 6 & 2.185 & 2,3-Butanedione & - & 2.37 & 3.40 & 5.7 \\
\hline 7 & 2.420 & Glycolaldehyde & - & - & 2.48 & - \\
\hline 8 & 3.145 & Acetic acid & - & 2.37 & - & - \\
\hline 9 & 5.820 & Furfural & 7.66 & 10.28 & 4.50 & 5.16 \\
\hline 10 & 6.275 & 2-Furfuryl alcohol & 7.30 & 3.34 & 7.67 & 3.08 \\
\hline 11 & 7.615 & $\begin{array}{l}\text { 1,2-Cyclopen- } \\
\text { tanedione }\end{array}$ & - & 1.40 & 3.25 & - \\
\hline 12 & 10.215 & $\begin{array}{l}2,5 \text {-Dimethyl-4- } \\
\text { hydroxy-3(2H)- } \\
\text { furanone }\end{array}$ & 1.92 & 1.29 & - & - \\
\hline 13 & 10.615 & Methyl 2-furoate & 2.02 & 1.91 & - & - \\
\hline 14 & 11.140 & Maltitol & 1.57 & - & - & - \\
\hline 15 & 11.720 & $\begin{array}{l}\text { 3,5-Dihydroxy-6- } \\
\text { methyl-2,3-dihydro- } \\
\text { 4H-pyran-4-one }\end{array}$ & 2.85 & - & - & - \\
\hline 16 & 13.265 & $\begin{array}{l}\text { 5-Hydroxymethyl } \\
\text { furfural }\end{array}$ & 50.92 & 31.99 & 13.9 & 8.96 \\
\hline 17 & 17.920 & $\begin{array}{l}\text { 1,6-Anhydro- } \beta \text {-D- } \\
\text { glucopyranose }\end{array}$ & 17.59 & 6.13 & 5.73 & - \\
\hline
\end{tabular}

further decreased, 1,6-anhydro- $\beta$-D-glucopyranose at that temperature can not be detected, which indicates that as the temperature rises further, the xylitol sample is easier to crack into carbon dioxide, aldehydes and ketones.

Table- 5 showed that the pyrolytic behaviour of sorbitol is completely different from the behavior of propylene glycol, glycerin, 27664 and xylitol, which mostly cracks into 1,4anhydroglucitol at the range of $300-600{ }^{\circ} \mathrm{C}$. At the condition of $300{ }^{\circ} \mathrm{C}$, acetone alcohol, 3-methyl-1,2-cyclopentanedione, 2-cyclopentene-1-one, isosorbide and 1,4-anhydroglucitol (5 kinds of material) are detected. At the condition of $450^{\circ} \mathrm{C}$, with a rise of temperature, carbon dioxide and acetaldehyde can be detected and the content of carbon dioxide is up to about $16 \%$. At $600{ }^{\circ} \mathrm{C}$, the pyrolysis product changes, which include harmful substances such as formaldehyde and acrolein. And isosorbide cannot be detected, corresponding to generating 3-hydroxybutyrate (content of 9.91\%). 1,4-Anhydroglucitol,

\begin{tabular}{|c|c|c|c|c|c|c|}
\hline \multicolumn{7}{|c|}{$\begin{array}{c}\text { TABLE-5 } \\
\text { PYROLYSIS PRODUCTS OF THE SORBITOL } \\
\text { AT DIFFERENT TEMPERATURES }\end{array}$} \\
\hline \multirow{2}{*}{ No. } & \multirow{2}{*}{$\begin{array}{l}\text { Residence } \\
\text { time } \\
\text { (min) }\end{array}$} & \multirow{2}{*}{ Products } & \multicolumn{4}{|c|}{ Relative content $(\%)$} \\
\hline & & & $300^{\circ} \mathrm{C}$ & $450^{\circ} \mathrm{C}$ & $600^{\circ} \mathrm{C}$ & $750^{\circ} \mathrm{C}$ \\
\hline 1 & 1.575 & Carbon dioxide & - & 15.98 & 5.33 & 28.16 \\
\hline 2 & 1.595 & Formaldehyde & - & - & 3.27 & 16.1 \\
\hline 3 & 1.69 & Acetaldehyde & - & 1.31 & 3.25 & 11.76 \\
\hline 4 & 1.81 & Acrolein & - & - & 2.51 & 7.49 \\
\hline 5 & 1.85 & Acetone & - & - & - & 6.65 \\
\hline 6 & 2.3 & 2,3-Butanedione & - & 1.07 & - & 4.08 \\
\hline 7 & 3.04 & $\begin{array}{l}\text { 1-Methyl-1,3- } \\
\text { cyclopentadiene }\end{array}$ & - & - & - & 6.68 \\
\hline 8 & 3.57 & Acetone Alcohol & 7.17 & - & - & - \\
\hline 9 & 9.635 & $\begin{array}{l}\text { 3-Methyl-1,2- } \\
\text { cyclopentanedione }\end{array}$ & 2.78 & 3.26 & 1.17 & 1.21 \\
\hline 10 & 10.105 & 2-cyclopenten-1-one & 1.11 & 1.13 & - & - \\
\hline 11 & 14.185 & Isosorbide & 10.64 & 2.28 & - & - \\
\hline 12 & 17.36 & 3-Hydroxybutyrate & - & - & 9.91 & - \\
\hline 13 & 22.64 & 1,4-Anhydroglucitol & 71.91 & 67.49 & 66.12 & - \\
\hline
\end{tabular}


the main pyrolysis products, changed a little $(66.12 \%)$. At $750{ }^{\circ} \mathrm{C}, 1,4$-Anhydroglucitol cannot be detected, other appropriate pyrolysis products such as carbon dioxide, formaldehyde, acetaldehyde, acrolein, acetone, 2,3-butanedione and 1-methyl-1,3-cyclopentadiene, respectively 28.16, 16.15, $11.765,7.49,6.65,4.08$ and $6.68 \%$, in which the harmful substances such as formaldehyde, acetaldehyde, acetone, aldehydes and ketones have high concentration, thus we should properly control the use of each of them.

\section{Conclusion}

Structures and properties of propylene glycol and glycerin are relatively stable, basically, the pyrolysis of them transfers by the manner of volatilization. The pyrolysis of propylene glycol shows that most volatile transfer of propylene glycol will increase the wet feeling of smoke and the pyrolysis of glycerol produced some low molecular aldehydes and ketones which is harmful. So the quantity of glycerol should be controlled, when it used as a additive.

In low temperature stage, the substance produced by the pyrolysis of xylitol basically have no obvious adverse effect on the quality of cigarettes, but in the high temperature stage it can produce large amounts of acetone aldehyde and formaldehyde which seriously affect the quality of cigarettes. So in terms of different temperature of pyrolysis, it must be strictly controlled when used as humectants.

Similarly, during high temperature stage of the pyrolysis of sorbitol, the amount of acrylic aldehyde, formaldehyde and other harmful substances have a dramatic increase, which do not good to the target of reducing danger of cigarettes. Most of our own production sample named 2247 happen to volatile transfer under high temperature in the processs of pyrolysis. Meanwhile, produce micro pyran substances which good for smoke and micro harmful acrylic aldehyde. More sensory evaluation tests still needed.

\section{REFERENCES}

1. A. Rodgman, Beitr. Tabakforsch. Int., 20, 279 (2002).

2. R.R. Baker and L.J. Bishop, J. Anal. Appl. Pyrolysis, 71, 223 (2004).

3. V. Oja, M.R. Hajaligol and B.E. Waymack, J. Anal. Appl. Pyrolysis, 76, 117 (2006)

4. $\quad$ E. Kleszczewska, Przegl. Lek., 64, 781 (2007).

5. A. Gómez Siurana, A. Marcilla, M. Beltran, I. Martinez, D. Berenguer, R. García-Martínez and T. Hernández-Selva, Thermochim. Acta, 523, 161 (2011).

6. R.R. Baker and L.J. Bishop, J. Anal. Appl. Pyrolysis, 74, 145 (2005).

7. T. Laino, C. Tuma, P. Moor, E. Martin, S. Stolz and A. Curioni, J. Phys. Chem. A, 116, 4602 (2012).

8. Z. Geng, M. Zhang and Y. Yu, Fuel, 93, 92 (2012). 